\title{
Gene Over Expression of Glycerol-3-phosphate Dehydrogenase in Some Marine Algae of Egypt.
}

\author{
H.A. Mansour, "M.A. Emam, M.M. Emam, A.M. Shaaban \\ and N. H. Mostafa \\ Department of Botany* and Biochemistry, Faculty of Sciences, \\ Ain Shams University, 11566, Cairo, Egypt.
}

\begin{abstract}
Q TUDIES focusing a survey or a comparison between freshwater and marine algae are relatively scarce. Some biochemical comparative study between three freshwater algae (Spirogyra reinhardii, Cladophora glomerata (green) and Chara vulgaris and six marine algae among them brown: Sargassum dentifolium, Padina boryana, Dictyota dichotoma; red: Gelidium latifolium, Gracilaria dura and green: Enteromorpha intestinalis) has been performed to study how marine algae can cope with salinity of seawater. Results obtained showed that fluorescence peaks were relatively uniform for the studied species within the same class but were different for different classes or divisions. The studied protein profile revealed the presence of three common protein bands $(125,15$ and $8 \mathrm{kDa})$ only in the members of euhalopic algal group and finally the presence of one common protein band $(240 \mathrm{kDa})$ only in all members of oligohalopic algae. The amount of proline showed irregular differences among the investigated marine and fresh algae. Mannitol was detected only in the members of brown algae. Moreover, the minerals (sodium and potassium) and glycerol contents of the marine algae have noticeable greater values than those of fresh algae. Glycerol-3-phosphate dehydrogenase (G3PDH) had a significant impact in the biosynthesis of glycerol. In the present study we explore the differential expression of $(\mathrm{G} 3 \mathrm{PDH})$ in marine algal group as compared to that of freshwater one. Results showed that, the expression level of (G3PDH) mRNA was significantly over expressed in marine algal group.
\end{abstract}

Keywords: Marine algae, Freshwater algae, Flourescence emission spectra, SDS-PAGE or protein profile, Mannitol, Proline, Minerals content, Glycerol-3-phosphate dehydrogenase.

Algae are a group of chlorophyll containing, oxygen-producing, photosynthetic organisms which are genetically diverse and inhabit a wide range of environments (Peerapornpisal et al., 2006). The characteristics of the organisms in each ecosystem relate directly to the conditions of the environment in that ecosystem. Algal cells are generally able to live within a certain range of enhanced salt concentrations or changing salinities since most probably all life originated in the oceans (Kirst, 1990 and Lionard et al., 2005). When organisms become acclimated to a new range of conditions, they generally lose the ability to perform well under the previous conditions. In the course of evolution, this phenomenon has resulted in two nearly separate groups of organisms: freshwater and marine (Hurd et al., 2014). In fact, the chemical composition of macro-algae varies considerably according to species and 
habitats (Gosch et al., 2012 and Jung et al., 2013). Although a lot of studies were carried out on marine macro-algae (Morgan et al., 1980; Castro-González et al., 1996 and Shuuluka et al., 2013), additional studies regarding the freshwater algae still needed to be carried out. Seaweeds are generally high in minerals contents due to their marine habitat. The mineral fraction of some seaweeds accounts for up to $36 \%$ of their dry matter (Burtin, 2003). Furthermore, studying of fluorescence emission spectra of chlorophyll may be a marker the algal environment (Topinka et al., 1990)

Moreover, protein pattern might play a critical role in the adaptation of algae to their natural habitat. Some specific polypeptides might provide osmotic adjustment to the cells either by facilitating the accumulation of solutes or by providing certain metabolic alterations in the cell, which may be helpful in osmotic adjustment (Singh et al., 1987 and Pareek et al. 1997). Algae can be counteracted different environmental stresses in their natural habitats (Lesser, 2006) through their contents from different highly compatible organic osmolytes to maintain osmotic pressure balance with the surrounding sea water (Iwamoto and Shiraiwa, 2005; Zubia et al., 2008). For most, if not all compatible solutes, it is assumed that they exert a direct protective effect on biomolecules against the damage of high concentrations of inorganic ions (Bisson and Kirst, 1995; Klähn and Hagemann, 2011). In algae, the compatible solutes are restricted to four major classes of solutes: sugars and polyols, free amino acids and derivate, quaternary ammonium compounds and tertiary sulphonium compounds (Garza- Sánchez et al., 2009).

In fact, the chemical composition of macro-algae varies considerably according to species and habitats (Gosch et al., 2012 and Jung et al., 2013). Although a lot of studies were carried out to estimate the protein and amino acid contents of marine macro-algae (Morgan et al., 1980; Castro-González et al., 1996 and Shuuluka et al., 2013), additional studies regarding the freshwater algae still needed to be carried out.

Proline, a compatible organic osmolyte, accumulates in some microalgae (Greenway and Setter, 1979; Ahmad and Hellebust, 1988; Kalinkina and Naumova, 1992 and Singh et al., 1996) and macroalgae (Edwards et al., 1987; Norziah and Ching, 2000) in response to hypersaline conditions. Proline accumulation is interpreted as providing a nontoxic osmolyte, a protectant of macromolecules and as a nitrogen-storage compound (Delauney and Verma, 1993; Szabados and Savoure, 2010). Polyols are important metabolites, because they exhibit multiple functions in metabolism; osmolytes, compatible solutes, rapidly available respiration substrates, antioxidant, etc. (Seckbach, 2007). Mannitol, one of the most widely occurring polyols, acts as a compatible solute and has multiple functions, including osmoregulation, storage, and regeneration of reducing power, and scavenging of active oxygen species (Yu et al., 2003; Iwamoto and Shiraiwa, 2005). Glycerol also is an important compatible solute and represents the simplest and the champion among all organic compatible solutes since it demands the least energetic cost and is the most hydrophilic compound (Rai and Gaur, 2012). However under highly saline conditions, 
glycerol is reported to accumulate to approximately $85 \%$ of the algal dry weight (Calvin and Taylor, 1989). Algae regularly face the adverse effects of salinity by adjustment of metabolism and gene expression for physiological adaptation.

Molecular and genomic analyses have shown that there are different transcriptional regulatory genes controlling various biological processes that trigger cell defenses (Dimova et al., 2008). Over-expression of these genes could enhance the biosynthesis of complex defense system. It was suggested that the overexpression level of G3PDH gene in the diatom cell; Phaeodactylum tricormutum enhanced the synthesis of glycerol (Yao et al., 2014). These may indicated that, algae exhibit a wide range of acclimation in response to induced salinity. However, studies focusing a survey or a comparison between freshwater and marine algae are relatively scarce. Moreover, the adaptation of marine algae to live in seawater has not been appreciated adequately by previous investigators. Therefore the objective of the current work is to obtain a comprehensive picture about the relative contribution of the algal groups in their natural habitats to glycerol-3-phosphate dehydrogenase (G3PDH) gene expression.

\section{Materials and Methods}

Sites of collection and the selected marine and freshwater algae

Nine algal species were investigated; six of them (Sargassum dentifolium, Padina boryana, Dictyota dichotoma, Gelidium latifolium, Gracilaria dura and Enteromorpha intestinalis) collected from marine (euhalopic) habitats; and three (Cladophora glomerata, Spirogyra reinhardii and Chara vulgaris) from freshwater (oligohalopic) habitats (Table 1). Four sites (Alexandria, Hurghada, Fayed and El-Qanater) were selected for algal collection to cover both euhalopic and oligohalopic ecosystem respectively.

Almost all algal samples were hand-picked and immediately washed with the surrounding water to remove extraneous matters, sand particles and epiphytes as much as possible. Then, they kept in ice box containing frozen gel cold packs to maintain the low temperature and moisture during the journey and immediately transported to the laboratory. On arrival, the algal samples were thoroughly washed with tap water and finally with distilled water. After that, the samples were spread on blotting paper to remove excess water. Only one algal species Chara vulgaris (Linnaeus) was laboratory tap water culture in transparent glass tanks supplemented continuously with water. Finally, cleaned algal samples were divided into two groups prior to the chemical analysis. In first group, samples were preserved in freezer for fresh weight analysis, second group was shaded air-dried, cut into small pieces and grounded into fine powder using a dry grinder and preserved for dry weight analysis. 
TABLE 1. Sites of collection, and algal groups, species and divisions.

\begin{tabular}{|c|c|c|c|c|}
\hline No. & Algal group & Division & Algal species & Collection site \\
\hline 1 & \multirow{6}{*}{$\begin{array}{l}\text { Marine group } \\
\text { (Euhalopic) }\end{array}$} & \multirow{3}{*}{$\begin{array}{l}\text { Phaeophyta } \\
\text { (Brown algae) }\end{array}$} & $\begin{array}{c}\text { Sargassum } \\
\text { dentifolium } \\
\text { (Turner) C. Agardh }\end{array}$ & \multirow{3}{*}{$\begin{array}{l}\text { Red Sea } \\
\text { (Hurgada) }\end{array}$} \\
\hline 2 & & & $\begin{array}{l}\text { Padina boryana } \\
\text { (L.) Gaill. }\end{array}$ & \\
\hline 3 & & & $\begin{array}{c}\text { Dictyota dichotoma } \\
\text { (hudson) } \\
\text { Lamouroux. }\end{array}$ & \\
\hline 4 & & \multirow{2}{*}{$\begin{array}{l}\text { Rhodophyta } \\
\text { (Red algae) }\end{array}$} & $\begin{array}{l}\text { Gelidium latifolium } \\
\text { (Grev.) Born. et. } \\
\text { Thur. } \\
\end{array}$ & $\begin{array}{c}\text { Mediterranean } \\
\text { Sea } \\
\text { (Alexandria) } \\
\end{array}$ \\
\hline 5 & & & $\begin{array}{l}\text { Gracilaria dura } \\
\text { (C. Ag.) J. Agardh. }\end{array}$ & $\begin{array}{c}\text { Suez Canal } \\
\text { (Fayed) }\end{array}$ \\
\hline 6 & & \multirow{3}{*}{$\begin{array}{l}\text { Chlorophyta } \\
\text { (Green algae) }\end{array}$} & $\begin{array}{c}\text { Enteromorpha } \\
\text { intestinalis } \\
\text { (Linnaeus) Link } \\
\end{array}$ & $\begin{array}{c}\text { Mediterranean } \\
\text { Sea } \\
\text { (Alexandria) } \\
\end{array}$ \\
\hline 7 & \multirow{3}{*}{$\begin{array}{l}\text { Freshwater } \\
\text { group } \\
\text { (Oligohalopic) }\end{array}$} & & $\begin{array}{l}\text { Cladophora } \\
\text { glomerata } \\
\text { (L.) Kütz }\end{array}$ & $\begin{array}{l}\text { River Nile } \\
\text { (El-Qanater) }\end{array}$ \\
\hline 8 & & & $\begin{array}{l}\text { Spirogyra } \\
\text { reinhardii }\end{array}$ & $\begin{array}{c}\text { Pool in } \\
\text { Borg El-Arab }\end{array}$ \\
\hline 9 & & Charophyta & $\begin{array}{l}\text { Chara vulgaris } \\
\text { (Linnaeus) }\end{array}$ & $\begin{array}{l}\text { Ain Musa } \\
\text { (Sinai) }\end{array}$ \\
\hline
\end{tabular}

\section{Sampling}

Almost all algal samples were hand-picked and immediately washed with the surrounding water to remove extraneous matters, sand particles and epiphytes as much as possible. Then, they kept in ice box containing frozen gel cold packs to maintain the low temperature and moisture during the journey and immediately transported to the laboratory. On arrival, the algal samples were thoroughly washed with tap water and finally with distilled water. After that, the samples were spread on blotting paper to remove excess water. Only one algal species Chara vulgaris (Linnaeus) was laboratory tap water culture in transparent glass tanks supplemented continuously with water. Finally, cleaned algal samples were divided into two groups prior to the chemical analysis. In first group, samples were preserved in freezer for fresh weight analysis, second group was shaded airdried, cut into small pieces and grounded into fine powder using a dry grinder and preserved for dry weight analysis.

\section{Algal identification}

Algal identification was based on morphological observations and/or sometimes on microscopical examination using microscope fitted with built-in digital camera. Samples were identified according to Knight and Park (1931),

Egypt. J. Bot., Vol. 56, No. 1 (2017) 
Zinova (1967), Papenfuss (1968), Jaasund (1976), Fedarov (1977), Abbott and Dawson (1978), Cribb (1983) and Aleem (1993).

Biochemical analysis of algae

Room temperature fluorescence emission spectra of pigments were performed using total pigments extracted from algal samples using Perkin Elmer LS50B spectrofluorometer according to Middleton et al., 1996. The determination, identification and characterization of different protein fractions were obtained using one-dimensional sodium dodecyl sulphate polyacrylamide gel electrophoresis. Polyacrylamide slab gel (12.5\%) was prepared according to Laemmli (1970). The distained gel was analyzed by Gel Documentation System (GDS). Gel analysis was performed in a GDS model UVP"s GDS 8000 from UVP Inc. (California 91786 USA), to analyze the band pattern, molecular weights and band percentages. Additionally, sodium, potassium, and calcium were estimated according to Ranganna (1977) using atomic absorption spectrophotometer (Pekrin Elmer USA 3100).

Moreover, mannitol and free proline were determined according to the method described by Cameron et al. (1948) and Bates et al. (1973) respectively. Glycerol was extracted from algal tissues according to the method adopted by Kochert (1978). Moreover, glycerol content was estimated according to Lambrt and Neish (1950). The name and sequence of the Oligonucleotide primers were reported according to the list of $\mathrm{Hu}$ et al. (2014). The fold change in G3PDH gene expression was calculated by normalizing with UBQ10 gene expression according to the following formula (Livak and Schmittgen, 2001)

\section{Statistic Analysis}

Data were subjected to an analysis of variance and the mean were compared using the least significant difference (LSD) test at the 0.05 level.

\section{Results and Discussion}

The feasibility of distinguishing macro-algal classes by their fluorescence peaks were investigated using narrow-wave band light to excite groups of accessory pigments in brown, red, and green macro-algae and measuring fluorescence emission. Members of Phaeophyta, Rhodophyta and Chlorophyta had distinctive fluorescence emission spectra when samples were excited at 435 nm.

The results (Fig. 1, a-i) indicated that, the excitation of the studied algal extracts at $435 \mathrm{~nm}$ causes fluorescence emission spectra of different peaks around 550, 680 and $700 \mathrm{~nm}$. Two Rhodophyta genera showed two main peaks; red chlorophyll fluorescence (RF) with emission around $700 \mathrm{~nm}$ and another larger peak around $550 \mathrm{~nm}$ (green fluorescence). These were more pronounced in comparison to the rest of the algal divisions. Excitation of Chlorophyta genera resulted in two peaks around 550 and $680 \mathrm{~nm}$ in both the freshwater (Fig. 1, a-c) and the marine algal group (Fig. 1, d-e). In Phaeophyta (Fig. 1, f-h), three peaks were recorded; two main peaks around 680 and $700 \mathrm{~nm}$ and one smaller peak 
around $550 \mathrm{~nm}$. The differences can be attributed to differences in accessory pigments between these divisions (Kancheva et al., 2005).

Results suggested that the changes in protein pattern might play a critical role in the adaptation of either group to their natural habitat.

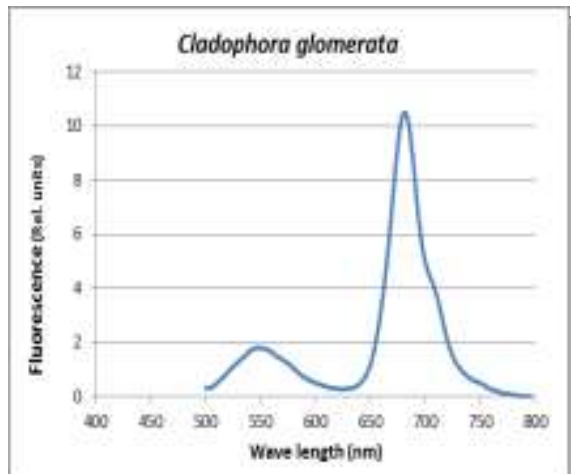

(a)

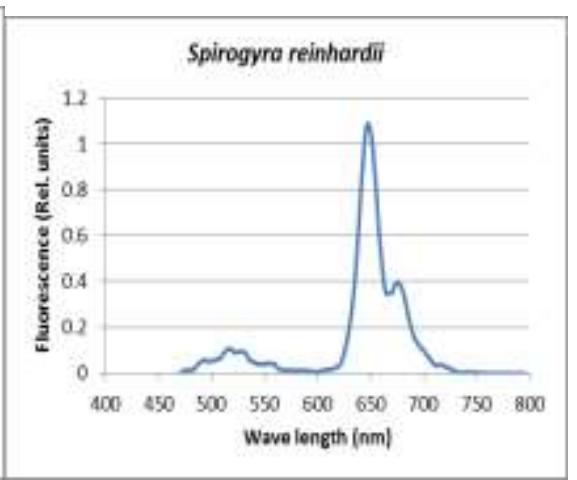

(b)

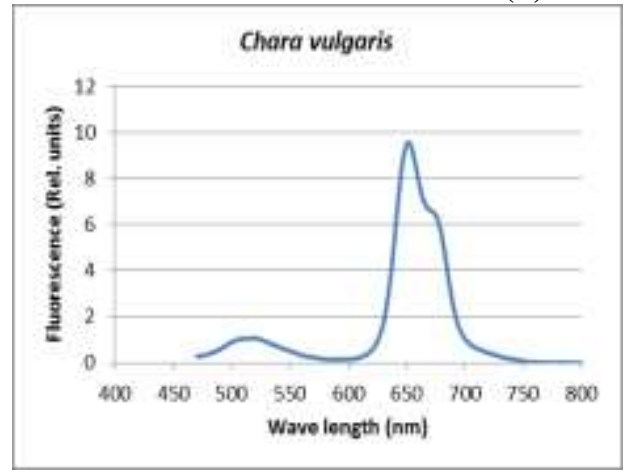

(c)

Figure (1, a-c): Emission spectra of the freshwater algae. $E_{x} \lambda=435 \mathrm{~nm}$

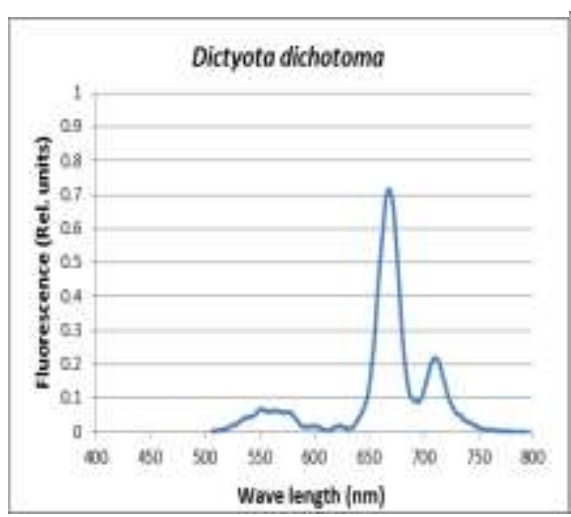

(d)

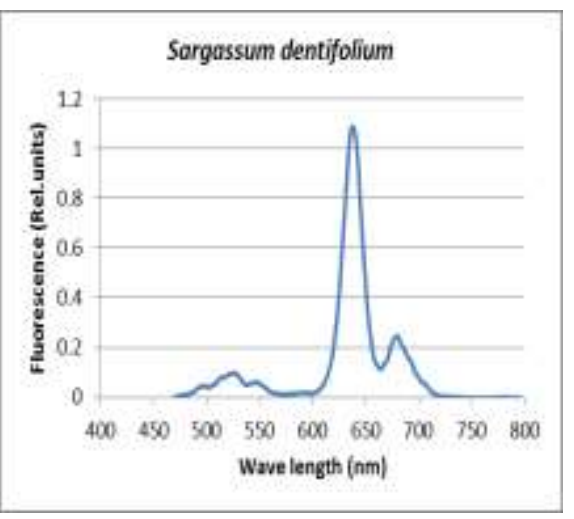

(e)

Egypt. J. Bot., Vol. 56, No. 1 (2017) 


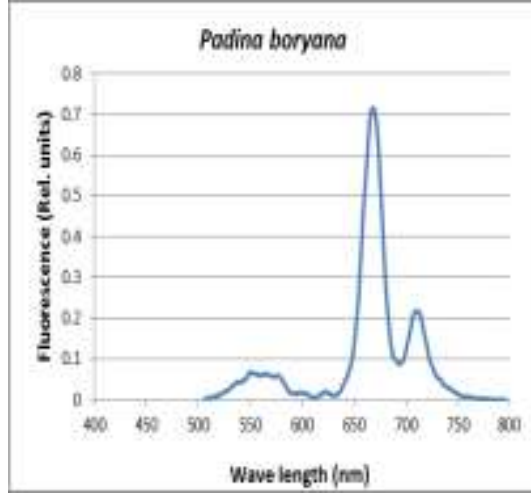

(f)

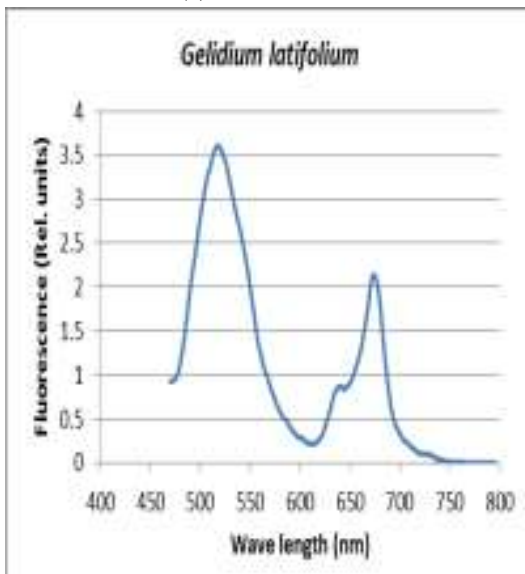

(h)

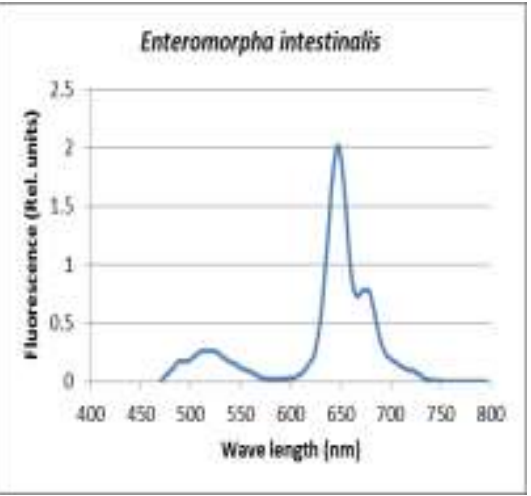

(g)

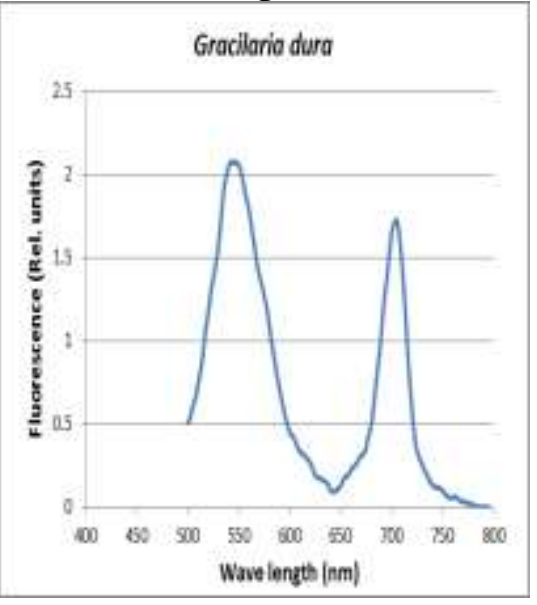

(i)

Fig. (1, d-i): Emission spectra of the marine algae. $E_{x} \lambda=435 \mathrm{~nm}$

The SDS-gel recorded the occurrence of three common protein bands (M.wt: 125,15 and $8 \mathrm{kDa}$ ) only in the majority of the marine algal members which were absent from the members of freshwater group (Fig. 1, a - i). According to Pareek et al. (1997), it is proposed that some proteins that accumulate in response to salinity may be considered as adaptive proteins. The presence of the low molecular weight protein $(8 \mathrm{kDa})$ in most of the marine algal species might explain the better performance of marine algae under saline conditions (Dunn, 1993). On the other hand, one specific protein band (M.wt: $240 \mathrm{kDa}$ ) was observed only in all members of the freshwater group which may be specific for this group. Also, the presence of certain characteristic protein banding pattern for each genus was noticed. Such results were consistent with the work carried out by Rouxel et al. (2001) and their proposal for species identification by SDSPAGE of red algae. 


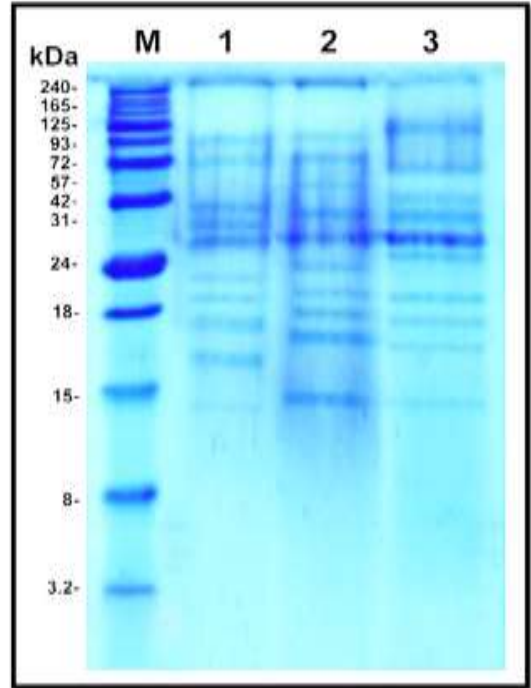

(a)

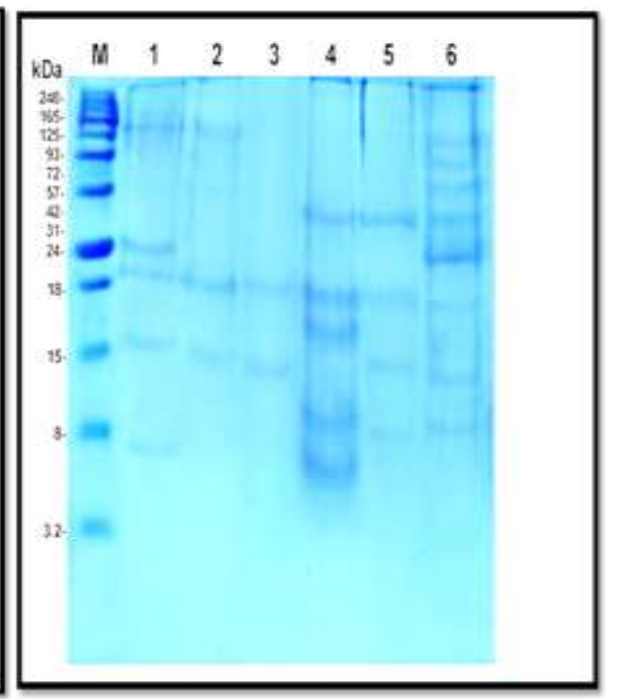

(b)

Fig. (2, a and b): (a) Electrograph SDS-PAGE of total soluble proteins extracted from the freshwater algal taxa, (b) Electrograph SDS-PAGE of total soluble proteins extracted from the marine algal taxa (M: Marker).

It is clearly shown that, the mineral contents (Table 2) particularly sodium, potassium and calcium of the marine algal taxa had a noticeable greater value $(\mathrm{P}<0.05)$ than those belonging to the freshwater group. The maximum sodium level $(\mathrm{P}<0.05)$ was recorded in Gracilaria dura $\left(30.44 \mathrm{mg}^{-\mathrm{g}^{-1}} \mathrm{DW}\right)$ followed by Enteromorpha intestinalis $\left(20.72 \mathrm{mg} \cdot \mathrm{g}^{-1} \mathrm{DW}\right)$ and Sargassum dentifolium $\left(16.04 \mathrm{mg} \cdot \mathrm{g}^{-1} \mathrm{DW}\right)$. The highest $(\mathrm{P}<0.05)$ potassium value was recorded in Sargassum dentifolium $\left(46.00 \mathrm{mg} \cdot \mathrm{g}^{-1} \mathrm{DW}\right)$ followed by Gracilaria dura $\left(45.24 \mathrm{mg} \cdot \mathrm{g}^{-1} \mathrm{DW}\right)$. The greatest calcium level $(\mathrm{P}<0.05)$ was detected in Sargassum. Dentifolium $\left(12.98 \mathrm{mg} \cdot \mathrm{g}^{-1} \mathrm{DW}\right)$. All the previous mentioned algal taxa belonging to the marine group.

According to previous studies by Arasaki and Arasaki (1983) and Nisizawa (2002) marine algae are known to be high in mineral content. This may be due to their marine habitat and the diversity of the minerals they absorb is wide (MacArtain et al., 2007). In addition, marine algae have the capacity to retain inorganic marine substances due to the characteristics of their cell surface polysaccharides (Rupérez, 2002; Bocanegra et al., 2009). 
TABLE 2. Minerals, Mannitol, Proline, Glycerol and level of Glycerol-3- phosphate dehydrogenase (G3PDH) transcript in freshwater and marine algal groups

\begin{tabular}{|c|c|c|c|c|c|c|c|c|c|c|}
\hline \multirow{3}{*}{$\begin{array}{l}\text { Algal } \\
\text { group }\end{array}$} & \multirow{3}{*}{$\begin{array}{c}\text { Algal } \\
\text { Species }\end{array}$} & \multirow{2}{*}{\multicolumn{4}{|c|}{ Minerals (mg.g $\left.{ }^{-1} \mathrm{dw}\right)$}} & \multirow{3}{*}{$\begin{array}{c}\text { Mannitol } \\
\text { mg.g }^{-1} \\
\text { dw }\end{array}$} & \multicolumn{2}{|c|}{ Proline Glycer } & \multirow{3}{*}{\begin{tabular}{|l|l|} 
Fold \\
change \\
$2^{-\triangle \Lambda C T}$
\end{tabular}} & \multirow{3}{*}{ Mean } \\
\hline & & & & & & & & & & \\
\hline & & $\begin{array}{c}\text { Sodium } \\
\left(\mathrm{Na}^{+}\right)\end{array}$ & $\begin{array}{c}\text { Potassiu } \\
\mathbf{m}\left(\mathbf{K}^{+}\right)\end{array}$ & $\underset{\left(\mathrm{Ca}^{+2}\right)}{\text { Calcium }}$ & $\mathrm{Na} / \mathrm{K}$ & & $\begin{array}{c}\mu \mathrm{\mu g} \cdot \mathrm{g}^{-1} \\
\mathrm{fw}\end{array}$ & $\begin{array}{c}\mu \mathrm{M} . \mathrm{g}^{-1} \\
\mathrm{fw}\end{array}$ & & \\
\hline \multirow{6}{*}{ 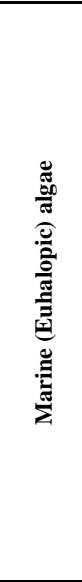 } & Sargassum dentifolium & $\begin{array}{l}16.04^{\mathrm{c}} \pm \\
0.32\end{array}$ & $\begin{array}{l}46.00^{\mathrm{a}} \\
\pm 0.73\end{array}$ & $\begin{array}{l}12.98^{\mathrm{a}} \\
\pm 0.25\end{array}$ & $\begin{array}{l}0.35^{\mathrm{e}} \\
\pm 0.008\end{array}$ & $\begin{array}{l}5.25^{\mathrm{b}} \\
\pm 0.05\end{array}$ & $\begin{array}{l}2.04^{\mathrm{d}} \\
\pm 0.03\end{array}$ & \begin{tabular}{|l|}
144.0 \\
$4^{\mathrm{b}}$ \\
\pm 1.2
\end{tabular} & \begin{tabular}{|l}
55.70 \\
${ }^{c_{ \pm}}$ \\
1.58
\end{tabular} & \multirow{6}{*}{$\begin{array}{l}53 . \\
605\end{array}$} \\
\hline & Padina boryana & $\begin{array}{l}5.00^{\mathrm{f}} \\
\pm 0.04\end{array}$ & $\begin{array}{l}15.40^{\mathrm{d}} \\
\pm 0.42\end{array}$ & $\begin{array}{l}5.26^{\mathrm{d}} \\
\pm 0.03\end{array}$ & $\begin{array}{l}0.32^{\mathrm{e}} \\
\pm 0.004\end{array}$ & $\begin{array}{l}5.10^{\mathrm{b}} \\
\pm 0.05\end{array}$ & $\begin{array}{l}2.25^{\mathrm{d}} \\
\pm 0.03\end{array}$ & \begin{tabular}{|l}
148.4 \\
$7^{\mathrm{b}} \pm$ \\
2.2
\end{tabular} & $\begin{array}{l}61.82 \\
\mathrm{~b}_{ \pm} \\
1.70\end{array}$ & \\
\hline & Dictyota dichotoma & $\begin{array}{l}5.60^{\mathrm{e}} \\
\pm 0.02\end{array}$ & $\begin{array}{l}37.50^{c} \\
\pm 0.51\end{array}$ & $\begin{array}{l}7.84^{\mathrm{c}} \\
\pm 0.08\end{array}$ & $\begin{array}{l}0.15^{\mathrm{f}} \\
\pm 0.004\end{array}$ & $\begin{array}{l}5.80^{\mathrm{a}} \\
\pm 0.04\end{array}$ & $\begin{array}{l}2.22^{\mathrm{d}} \\
\pm 0.04\end{array}$ & $\begin{array}{l}238.5 \\
1^{\mathrm{a}} \\
\pm 2.9 \\
\end{array}$ & \begin{tabular}{|l}
106.8 \\
$9^{\mathrm{a}}$ \\
\pm 3.06
\end{tabular} & \\
\hline & Gelidium latifolium & $\begin{array}{l}9.96^{\mathrm{d}} \pm 0 \\
.07\end{array}$ & \begin{tabular}{|l|}
$7.50^{\mathrm{g}} \pm 0$ \\
.30
\end{tabular} & $\begin{array}{l}3.21^{\mathrm{f}} \pm 0 \\
.02\end{array}$ & $\begin{array}{l}1.33^{\mathrm{b}} \pm 0 \\
016\end{array}$ & - & $\begin{array}{l}12.58 \\
{ }^{\mathrm{a}} \pm 0.6 \\
3 \\
\end{array}$ & $\begin{array}{l}136.3 \\
5^{c} \pm 3\end{array}$ & $\begin{array}{l}46.52 \\
\mathrm{~d} \pm 1.3 \\
3\end{array}$ & \\
\hline & Gracilaria durra & $\begin{array}{c}30.44^{\mathrm{a}} \pm \\
0.61\end{array}$ & $\begin{array}{c}45.24^{\mathrm{b}} \pm \\
0.82\end{array}$ & $\begin{array}{c}2.64^{\mathrm{g}} \pm 0 \\
.03\end{array}$ & $\begin{array}{c}0.67^{\mathrm{c}} \pm 0 . \\
007\end{array}$ & - & $\begin{array}{l}3.47^{\mathrm{c}} \\
\pm 0.12\end{array}$ & $\begin{array}{c}129.4 \\
9^{d} \pm 0 . \\
9\end{array}$ & \begin{tabular}{|c|}
39.39 \\
${ }^{e} \pm 1.1$ \\
4
\end{tabular} & \\
\hline & \begin{tabular}{|l}
$\begin{array}{l}\text { Enteromorpha } \\
\text { intestinalis }\end{array}$ \\
\end{tabular} & $\begin{array}{c}20.72^{b} \pm \\
0.43\end{array}$ & \begin{tabular}{|c|}
$9.30^{\mathrm{f}} \pm 0$ \\
.21
\end{tabular} & \begin{tabular}{|c|}
$4.52 \pm 0$. \\
04
\end{tabular} & $\begin{array}{c}2.23^{\mathrm{a}} \pm 0 . \\
017\end{array}$ & - & \begin{tabular}{|l|}
$4.33^{b}$ \\
\pm 0.22 \\
\end{tabular} & $\begin{array}{c}52.23^{\mathrm{f}} \\
\pm 0.4 \\
\end{array}$ & \begin{tabular}{|l|}
$11.31^{\mathrm{f}}$ \\
\pm 0.33 \\
\end{tabular} & \\
\hline \multirow{3}{*}{ 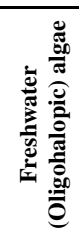 } & Cladophora glomerata & $\begin{array}{c}2.20^{\mathrm{g}} \pm 0 \\
.03 \\
\end{array}$ & $\begin{array}{c}4.97^{\mathrm{h}} \pm 0 \\
.18 \\
\end{array}$ & $\begin{array}{c}2.48^{\mathrm{g}} \pm 0 \\
.01\end{array}$ & $\begin{array}{c}0.44^{\mathrm{d}} \pm 0 . \\
016 \\
\end{array}$ & - & $\begin{array}{l}2.24^{\mathrm{d}} \\
\pm 0.01 \\
\end{array}$ & \begin{tabular}{l|}
42.71 \\
$\mathrm{~g}_{ \pm} 0.3$ \\
\end{tabular} & \begin{tabular}{|r|}
$2.77^{\mathrm{g}}$ \\
\pm 0.04 \\
\end{tabular} & \multirow{3}{*}{2.03} \\
\hline & Spirogyra reinhardii & $\begin{array}{c}0.98^{\mathrm{h}} \pm 0 \\
.01\end{array}$ & $\begin{array}{c}11.36^{\mathrm{e}} \pm \\
0.33\end{array}$ & $0.87^{\mathrm{i}} \pm 0$ & $\begin{array}{c}0.08^{\mathrm{g}} \pm 0 \\
002\end{array}$ & - & $\begin{array}{c}0.63^{\mathrm{e}} \\
\pm 0.10\end{array}$ & $\begin{array}{l}9.48^{\mathrm{h}} \\
\pm 0.05\end{array}$ & $\begin{array}{c}1.00^{\mathrm{g}} \\
\pm 0.02\end{array}$ & \\
\hline & Chara vulgaris & $0.15^{\mathrm{i}} \pm 0$ & $\begin{array}{c}4.39^{\mathrm{hi}} \pm \\
0.19\end{array}$ & $\begin{array}{c}10.77^{\mathrm{b}} \pm \\
0.15\end{array}$ & $\begin{array}{c}0.03^{\mathrm{h}} \pm 0 \\
003\end{array}$ & - & $\begin{array}{l}1.24^{\mathrm{e}} \\
\pm 0.04\end{array}$ & $\begin{array}{l}40.88 \\
\mathrm{~g}_{ \pm} 0.6\end{array}$ & $\begin{array}{c}2.34^{\mathrm{g}} \\
\pm 0.06\end{array}$ & \\
\hline
\end{tabular}

The minimum $\mathrm{Na}^{+} / \mathrm{K}^{+}$value was recorded in the oligohalopic Spirogyra spp. (0.03), whereas the marine Enteromorpha intestinalis had the highest value (2.23). Sodium and potassium play an important role in the electrolyte balance (Krishnaiah et al., 2008). Osmoregulation in marine algae are mainly maintained by $\mathrm{Na}^{+}$and $\mathrm{K}^{+}$pump operating between seawater and cell sap to attain high $\mathrm{Na}^{+}$to $\mathrm{K}^{+}$ratio (Eisler, 1980). It is interesting to note here that the $\mathrm{Na}^{+} / \mathrm{K}^{+}$were below 0.8 in most algal taxa under investigation. From the nutritional point of view, the intake of sodium chloride in diets with a high $\mathrm{Na}^{+}$to $\mathrm{K}^{+}$ratio, have been related to the incidence of hypertension (Dahl et al., 1972). Such result indicates that the algal taxa in the present investigation can be used as a concentrated form of mineral supplements (with a low $\mathrm{Na}^{+} / \mathrm{K}^{+}$) in comparison with land vegetables (Dawczynski et al., 2007; Astorga-España et al., 2015 ).

It was expected that all marine algal species under investigation accumulate high proline contents (Table 2); however it is apparent that this is especially true only for the marine red alga; Gelidium latifolium. Similarly, Gressler et al. (2010) recorded the high proline content in several red algae. The current results 
revealed also that, despite the scarcity of proline in spirogyra reinhardii and Chara vulgaris, some marine algae as Dictyota dichotoma and Sargassum dentifolium exhibited also low proline content. This observation weakens the hypothesis that proline is the major osmolyte in marine algae inhabiting sea water.

Our Results also showed that, mannitol was recorded only in members of brown algae (Table 2). It is worth to note here that mannitol is the primary product from photosynthesis in brown algae (Thomas and Subbaramaiah, 1991). In addition, it is the main reserve polysaccharide (Horn et al., 2000). Further, accumulation of low molecular weight carbohydrates such as mannitol in various brown algal species under salinity has strongly suggested their involvement in the process of osmotic adjustment and osmo-protection (Karsten, 2012 and Groisillier et al., 2014).

The present study revealed also that, the highest glycerol contents were measured in all the members of marine group dominated by brown algae followed by red algae and finally green algae (Table 2, Fig 3). In contrast, freshwater members have the lowest glycerol contents as presented by reinhardii. The highest glycerol content was detected in Dictyota dichotoma (238.51 $\mu \mathrm{M} . \mathrm{g}-1 \mathrm{fw})$ followed by Gelidium latifolium (136.35 $\mu \mathrm{M} . \mathrm{g}-1 \mathrm{fw})$ and finally Enteromorpha intestinalis $(52.23 \mu \mathrm{M} . \mathrm{g}-1 \mathrm{fw})$. On the other hand, glycerol content represented the lowest values in the oligohalopic alga Spirogyra reinhardii. (9.48 $\mu \mathrm{M} . \mathrm{g}-1 \mathrm{fw})$. It was reported that, the accumulation of glycerol was activated by extreme salinity of seawater thus glycerol may act as osmoregulator (Borowitzka and Borowitzka, 1988) to enable marine algae to survive at high salinities of seawater. The observed high content of glycerol (Table 2) in the investigated marine algae may be due to the protective effect of glycerol on the stability of photosystem II protein complexes (Khristin and Simonova, 1998; Allakhverdiev et al., 2000). In addition, accumulation of glycerol allows survival at high sodium concentration (Borowitzka and Borowitzka, 1988). Brown and Borowitzaka (1979) reported that, glycerol are capable of adjusting the osmotic balance without affecting enzyme activities.

The osmotic acclimation effect of glycerol has been recognized early in few members of marine algae (Ben-Amotz and Avron, 1980; Siaut et al., 2011; Yao et al., 2014). However, how it is involved in defense responses and adaptation of marine algae has not been investigated. Allam (1994) algae which can cope with wide range of salinity levels may have specific or characteristic genes which can show their expressions only under environmental stresses. The same author reported that most or all of these genes are suppressed again when the external stresses disappeared. In this respect, our study aims to look for specific genes that have high expression only in members of marine algae in their natural habitat. Moreover, one of the important tasks we chose is to gain preliminary insights about the transcriptional responses of glycerol-3-phosphate dehydrogenase (G3PDH is the key enzyme in glycerol biosynthesis).

Egypt. J. Bot., Vol. 56, No. 1 (2017) 


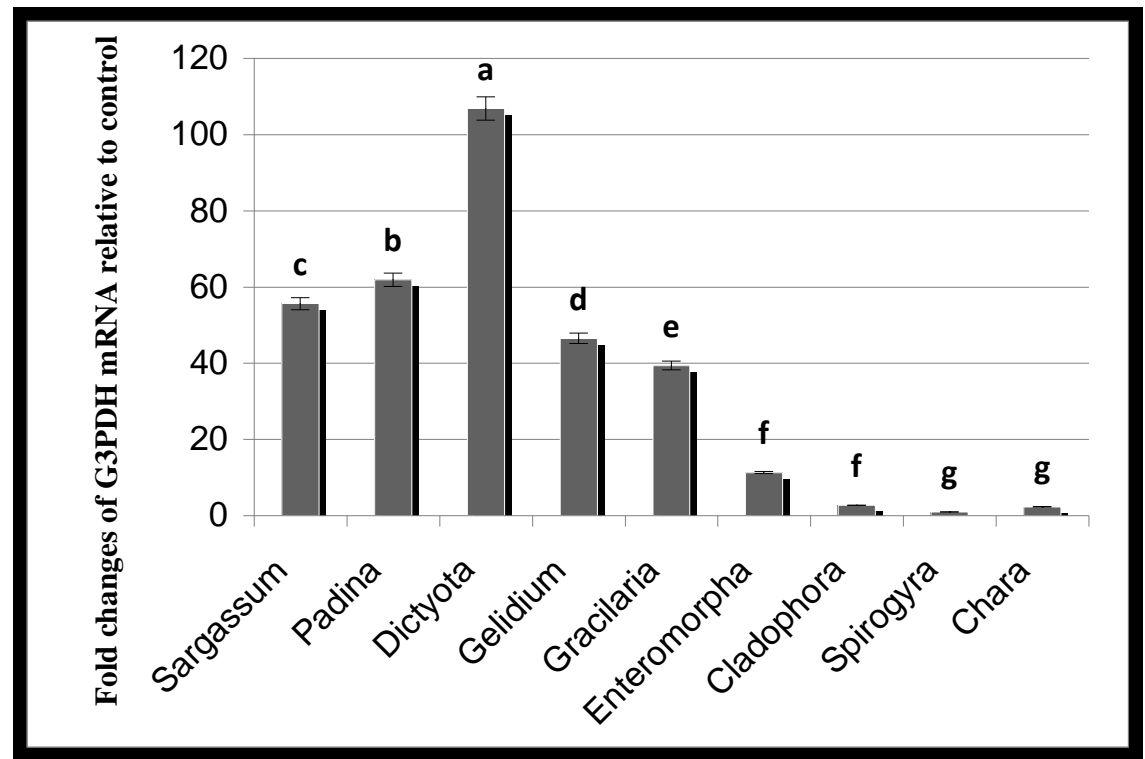

Fig. 3. Expression level of G3PDH mRNA in freshwater and marine algal groups compared to UBQ10.

The qRT-PCR analysis revealed that, the expression level of G3PDH mRNA was significantly up-regulated $(\mathrm{p}<0.05)$ in marine algal groups, as compared to that of the freshwater algae (Table 3, fig. 4, a and b). However, the changes in G3PDH expression levels of euhalopic was about 23-fold higher than that observed in the freshwater taxa. The results (Table 2) revealed two different patterns in the level of G3PDH transcript ranged from 9.19 to 106.89 in the marine group while it ranged from 1.0 to 2.77 in members of freshwater group. In the marine group, maximum levels of G3PDH transcript were measured in Dictyota dichotoma (106.8) followed by Padina boryana and Sargassum dentifolium (61.8 and 55.7 respectively). The lowest levels were detected in Enteromorpha intestinalis (11.31), while moderate levels were noticed in the members of red algae; Gelidium latifolium and Gracilaria dura (46.5 and 39.3 respectively).On the other hand, only small changes in G3PDH expression were observed in members belonging to the freshwater group; where the highest level was observed in Cladophora glomerata (2.77), however the lowest expression was found in Spirogyra reinhardii (1.0). Comparing with the increased expression level of G3PDH in all marine taxa under investigation, we found decreased level in freshwater taxa indicating that Glycerol-3-phosphate dehydrogenase (G3PDH) was found to play a role in osmo-adaptation (Yao et al., 2014).

Overall, the current work represented an important step toward understanding the mechanisms involved in salinity adaptation of the marine algae in their natural habitat. However, more studies are needed to investigate the other metabolic pathways which regulate the accumulation of glycerol to enable marine algae to 
survive in seawater. It is still open question whether all algae thriving in saline environments exhibit overexpression of glycerol-3-phosphate dehydrogenase (G3PDH).

\section{References}

Abbott, I.A. and Dawson, E.Y. (1978) How to know the seaweeds. In: "The Pictured Key Nature Series $\left(2^{\text {nd }}\right.$ ed). Dubuque, Iowa, USA: Wm. C. Brown Company publishers, Pp 141.

Ahmad, I. and Hellebust, J.A. (1988) The relationship between inorganic nitrogen metabolism and proline accumulation in osmoregulatory responses of two euryhaline microalgae. Plant Physiology, 88 (2): 348-354.

Aleem, A.A. (1993) "The Marine Algae of Alexandria", Egypt. Egypt: University of Alexandria Publications, Pp 138. (privately published).

Allakhverdiev, S. I., Sakamoto, A., Nishiyama, Y. Inaba, M. and Murata, N. (2000) Ionic and osmotic effects of NaCl-induced inactivation of photosystems I and II in Synechococcus sp. Plant Physiology, 123 (3): 1047-1056.

Arasaki, A. and Arasaki, T. (1983) Low calories, High Nutrition. In: "Vegetables from the Sea to Help you Look and Feel Better". Tokyo: Japan Publications Inc, Pp: 39-42.

Astorga-España, M.S., Galdón, B.R., Rodríguez, E.R., Romero, C. D. (2015) Mineral and trace element concentrations in seaweeds from the sub-Antarctic ecoregion of Magallanes (Chile). Journal of Food Composition and Analysis, 39: 69-76.

Bates, L.S., Waldren, R.P. and Tear, I.D. (1973) Rapid determination of free proline for water-stress studies. Plant and Soil, 39: 205-207.

Ben-Amotz, A., Sussman, I. and Avron, M. (1982) Glycerol production by Dunaliella. Experientia, 38(1): 49-52.

Bisson, M.A. and Kirst, G.O. (1995) Osmotic acclimation and turgor pressure regulation in algae. Naturwissenschaften, 82: 461-471.

Bocanegra, A., Bastida, S., Benedí, J., Ródenas, S. and Sánchez-Muniz, F.J. (2009) Characteristics and nutritional and cardiovascular-health properties of seaweeds. Journal of Medicinal Food, 12(2): 236-258.

Borowitzka, M.A. and Borowitzka, L.J. (1988) Vitamins and fine chemicals from micro-algae. In: "Microalgal biotechnology". Cambridge: Cambridge University Press, Pp: 153-196.

Brown, A.D. and Borowitzaka, L.J. (1979) Halotolerance of Dunaliella. In: Biochemistry and physiology of protozoa M Leveandowsky, SH Hunter (Eds). (Vol. I). New York: Academic Press, Pp. 139-190.

Burtin, P. (2003) Nutritional value of seaweeds. Electronic Journal of Environmental, Agricultural and Food Chemistry, 2(4): 498-503.

Egypt. J. Bot., Vol. 56, No. 1 (2017) 
Cameron, M.C., Ross, A.G. and Percival, E.G.V. (1948) Methods for the routine estimation of mannitol, alginic acid, and combined fucose in seaweeds. Journal of the Society of Chemical Industry (London), 67:161-164.

Castro-Gonzales, M.I., Perez-Gil Romo, F., Perez-Estrella, S. and CarilloDominguez, S.D. (1996) Chemical composition of the green alga Ulva lactuca 'in Ciencas Marinas, 22: 205-213.

Calvin, M., Taylor, S. E. (1989) Fuels from algae. In: "Algal and cyanobacterial biotechnology" RC Cresswell, TAV Rees, N Shah (Eds). Essex (UK): Longman scientific and technical, Pp: 137-160.

Cribb, A.B. (1983) “Marine algae of the southern Great Barrier Reef'. Part I Rhodophyta. Brisbane, Australia: Watson Ferguson \& Co., Pp 175.

Dahl, L.K., Leitl, G. and Heine, M. (1972) Influence of dietary potassium and sodium/potassium molar ratios on the development of salt hypertension. The Journal of Experimental Medicine, 136 (2): 318.

Dawczynski, C., Schäfer, U., Leiterer, M., Jahreis, G. (2007) Nutritional and toxicological importance of macro, trace, and ultra-trace elements in algae food products. Journal of Agricultural and Food Chemistry, 55(25): 10470-10475.

Delauney, A.J. and Verma, D.P.S. (1993) Proline biosynthesis and osmoregulation in plants. The Plant Journal, 4: 215-223.

Dimova, E.G., Bryant, P.E. and Chankova, S.G. (2008) Adaptive response" - Some underlying mechanisms and open questions. Genetics and Molecular Biology, 31 (2): 396-408.

Dunn, M. J. (1993) "Gel Electrophoresis: Proteins". Oxford: Bios Scientific Publishers, Ltd, Pp 176.

Edwards, D.M., Reed, R.H., Chudek, J.A., Foster, R. and Stewart, W.D.P. (1987) Organic solute accumulation in osmotically-stressed Enteromorpha intestinalis. Marine Biology, 95 (4): 583-592.

Eisler, R. (1980) Accumulation of Zinc by marine biota. In: "Zinc in Environment". Part 2: Health Effects., J.O. Nriagu (Ed). John Wiley, NY, pp. 259-351.

Fedarov, A. (1977) "Plant Life" in six volumes (Vol. 3). MM Gollerbach. Algae and lichens. Moscow: Prosveschenie, $\mathrm{Pp} 488$.

Garza-Sánchez, F., Chapman, D.J., Cooper, J.B. (2009) Nitzschia ovalis (Bacillariophyceae) Mono Lake strain accumulates $1,4 / 2,5$ cyclohexanetetrol in response to increased salinity. Journal of Phycology, 45: 395-403.

Gosch, B.J., Magnusson, M., Paul, N.A., Nys, R. (2012) Total lipid and fatty acid composition of seaweeds for the selection of species for oil - based biofuel and bioproducts. Global Change Biology Bioenergy, 4(6): 919-930. 
Greenway, H. and Setter, T. L. (1979) Accumulation of Proline and Sucrose during the First Hours after Transfer of Chlorella emevsonii to High NaCl. Functional Plant Biology, 6(1): 69-79.

Gressler V, Yokoya NS, Fujii MT, Colepicolo P, Mancini J, Torres RP and Pinto E. (2010) Lipid, fatty acid, protein, amino acid and ash contents in four Brazilian red algae species. Food Chemistry, $120: 585-590$.

Groisillier, A., Shao, Z., Michel, G., Goulitquer, S., Bonin, P., Krahulec, S., Nidetzky B, Duan D, Boyen C. and Tonon, T. (2014) Mannitol metabolism in brown algae involves a new phosphatase family. Journal of Experimental Botany, 65 (2): 559-570.

Horn, S.J., Aasen, I.M. and Østgaard, k. (2000) Production of ethanol from mannitol by Zymobacter palmae. Journal of Industrial Microbiology and Biotechnology, 24: 51-57.

Hu, J., Zhang, Y., Wang, J. and Zhou, Y. (2014) Glycerol affects root development through regulation of multiple pathways in Arabidopsis. PLOS ONE, 9 (1): e86269.

Hurd, C.L., Harrison, P.J., Bischof, K. and Lobban, C.S. (2014) Seaweed Ecology and Physiology. UK: Cambridge University Press, Pp 562.

Ibraheem, I.B.M., Alharbi, R.M., Abdel-Raouf, N. and AlEnazi, N.M. (2014) Contributions to the study of the marine algae inhabiting Umluj Seashore, Red Sea. Beni-suef university journal of basic and applied sciences 3:278-285.

Iwamoto, K., Shiraiwa, Y. (2005) Salt-regulated mannitol metabolism in algae. Marine Biotechnology, 7(5): 407-415.

Jaasund, E. (1976) “Intertidal seaweeds in Tanzania" ( $1^{\text {st }}$ ed.) University of Tromso, Pp, 160.

Jung, K.A., Lim, S.R., Kim, Y. and Park, J.M. (2013) Potentials of macroalgae as feedstocks for biorefinery. Bioresource technology, 135: 182-190.

Kalinkina, L.G. and Naumova, T.G. (1992) Content of free amino-acids in cells of marine and fresh-water Chlorella during inhibition of the glycolate pathway on a background of salinity. Soviet Plant Physiology, 39 (3): 358-365.

Kancheva, R., Iliev I., Borisova, D., Chankova, S. and Kapchina, V. (2005) Detection of Plant Physiological Stress Using Spectral Data. Ecological Engineering and Environment Protection, 1: 4-9.

Karsten, U. (2012) Seaweed acclimation to salinity and desiccation stress. In: C Wiencke, k. Bischof (Eds) Ecological Studies.Seaweed Ecophysiology and Ecology (Vol. 219). Berlin: Springer, Pp: 87-107.

Khristin, M.S. and Simonova, N.B. (1998) Effect of glycerol on stability and extraction of Photosystem II pigment-proteins complexes from membranes of the unicellular green algae Dunaliella salina. Биологические мембраны, 15 (1): 54-55.

Kirst, G.O. (1990) Salinity tolerance of eukaryotic marine algae. Annual Review of Plant Biology, 41(1): 21-53.

Egypt. J. Bot., Vol. 56, No. 1 (2017) 
Klähn, S. and Hagemann, M. (2011) Compatible solute biosynthesis in cyanobacteria. Environmental microbiology, 13 (3): 551-562.

Knight, M. and Park, M. (1931) "Manx Algae". An algal survey of the south end of the isle of man. L.M.B.C Memoirs, Liverpool Univ. Press, 30: 1-147.

Kochert, G. (1978) Carbohydrate determination by the phenol-sulfuric acid method. In "Handbook of Phycological Methods: Physiological And Biochemical Methods. London: Cambridge University Press, Pp: 95-97.

Kolbe, R.W. (1927) Zur Ökologie, Morphologie und Systematik der Brackwasserdiatomeen. Die Kieselalgen des Sperenberger Salzgebietes. Pflanzenforsch. VII, Pp: 1-146.

Krishnaiah, D., Sarbatly, R., Prasad, D.M. R. and Bono, A. (2008) Mineral content of some seaweeds from Sabah's South China Sea. Asian Journal of Scientific Research, 1 (2): 166-170.

Laemmli, U.K. (1970) Cleavage of structural proteins during the assembly of the head of bacteriophage T4. Nature, 227: 680- 685 .

Lambert, M. and Neish, A.C. (1950) Rapid method for estimation of glycerol in fermentation solutions. Canadian Journal of Research, 28: 83-89.

Lesser, M.P. (2006) Oxidative stress in marine environments: biochemistry and physiological ecology. Annual Reviews of Physiology, 68: 253-278.

Lionard, M., Muylaert, K., Van Gansbeke, D., Vyverman, W. (2005) Influence of changes in salinity and light intensity on growth of phytoplankton communities from the Schelde river and estuary (Belgium/The Netherlands). Hydrobiologia, 540 (1-3): 105-115.

Livak, K.J. and Schmittgen, T.D. (2001) Analysis of relative gene expression data using real time quantification PCR, the 2- $\Delta \Delta C t$. Methods, 25: 402-408.

MacArtain, P., Gill, C.I., Brooks, M., Campbell, R., Rowland, I.R. (2007) Nutritional value of edible seaweeds. Nutrition Reviews, 65 (12): 535-543.

Middleton, E.M., Chappelle, E.W., Cannon, T.A., Adamse, P. and Britz, S.J. (1996) Initial assessment of physiological response to UV-B radiation using fluorescence measurements. J. Plant Physiol., 148: 69-77.

Morgan, K.C., Wright, J. L.C. and Simpson, F.J. (1980) Review of chemical constituents of the red alga Palmaria palmata (Dulse). Economic Botany, 34: 27-50.

Nishizawa, K. (2002) "Seaweeds kaiso": bountiful harvest from the seas: sustenance for health \& well being by preventing common life-style related diseases. Kochi: Kochi University, Pp 106.

Norziah, M.H. and Ching, C.Y. (2000) Nutritional composition of edible seaweed Gracilaria changgi. Food Chemistry, 68 (1): 69-76. 
Papenfuss, G. F. (1968) A history, catalogue, and bibliography of the Red Sea benthic algae. Israel Journal of Botany, 17: 1-118.

Pareek, A., Singla, S.L. and Grover, A. (1997) Salt responsive proteins/genes in Crop plants. In: (Eds) "Strategies For Improving Salt Tolerance In Higher Plants. PK Jiawal, RP Singh, A Gulat PK Jiawal, RP Singh, A Gulat Newdelhi: Oxford and IBH Publ. Co., Pp: 365-391.

Peerapornpisal, Y., Doungporn, A., Chaiyong, R., Khomson, R. and Duangta, K. (2006) Two endemic species of macroalgae in Nan River, Northern Thailand, as therapeutic agents. Science Asia, 32: 71-76.

Ranganna, S. (1977) "Manual Analysis of Fruits and Vegetables Products". New Delhi: Mc Grow-Hill Publishing Company, Pp 363.

Rai, L.C., Gaur, J.P. (2012) Algal Adaptation to Environmental Stresses: Physiological, Biochemical and Molecular Mechanisms. Berlin: Springer, Pp 421.

Rouxel, C., Daniel, A., Jérôme, M., Etienne, M., Fleurence, J. (2001) Species identification by SDS-PAGE of red algae used as seafood or a food ingredient. Food Chemistry, 74 (3): 349- 353.

Ruperez, P. (2002) Mineral content of edible marine seaweeds. Food Chemistry, 79: 2336.

Seckbach, J. (2007) Algae and cyanobacteria in extreme environments (Vol.11). Netherland: Springer, Pp 814.

Shuuluka, D., Bolton, J.J. and Anderson, R.J. (2013) Protein content, amino acid composition and nitrogen-to-protein conversion factors of Ulva rigida and Ulva capensis from natural populations and Ulva lactuca from an aquaculture system, in South Africa. Journal of Applied Phycology, 25 (2): 677-685.

Siaut, M., Cuiné, S., Cagnon, C., Fessler, B., Nguyen, M., Carrier, P., Beyly, A., Beisson, F., Triantaphylidès, C. and Li-Beisson, Y. (2011) Oil accumulation in the model green alga Chlamydomonas reinhardtii: characterization, variability between common laboratory strains and relationship with starch reserves. BioMedCentral Biotechnology, 11:1-7.

Singh, N.K., Brecker, C.A., Hasegawa, P.M., Handa, A.K., Buckel, S., Hermodson, M.A., Pfankoch, E., Regnier, F.E. and Bressan, R.A. (1987) Characterization of osmotin. A thaumatin-like protein associated with osmotic adaptation in plant cells. Plant Physiology, 85, 529-536.

Singh, A. K., Chakravarthy, D., Singh, T.P.K. and Singh, H.N. (1996) Evidence for a role for L-proline as a salinity protectant in the cyanobacterium Nostoc muscorum. Plant Cell and Environment, 19: 490-494.

Szabados, L., Savoure, A. (2010) Proline: a multifunctional amino acid. Trends in Plant Science, 15 (2): 89-97.

Egypt. J. Bot., Vol. 56, No. 1 (2017) 
Tan KH (1996) “Soil sampling, preparation and analysis”. Marcel Dekker, Inc., New York. 408 pp.

Thomas, P.C. and Subbaramaiah, K. (1991) Seasonal variations in growth, reproduction, alginic acid, mannitol, iodine and ash contents of brown alga Sargassum wightii. Indian Journal of Marine Sciences, 20: 169-175.

Yao, Y., Lu, Y., Peng, K. T., Huang, T., Niu, Y. F., Xie, W.H. ... and Li, H. Y. (2014) Glycerol and neutral lipid production in the oleaginous marine diatom Phaeodactylum tricornutum promoted by overexpression of glycerol-3-phosphate dehydrogenase. Biotechnology for Biofuels, 7 (1): 1-9.

Yu, T., Bai, J., Hu, K., Wang, Z. (2003) The effect of free radical scavenger and antioxidant on the increase in intracellular adriamycin accumulation induced by ultrasound. Ultrasonics Sonochemistry, 10 (1): 33-35.

Zinova, A. D. (1967) "Classifier of Green, Brown and Red Algae of Southern Seas of the USSR”. Moscow. Leningrad: Nauka ANUSSR, Pp 399.

Zubia, M., Payri, C. and Deslandes, E. (2008) Alginate, mannitol, phenolic compounds and biological activities of two range-extending brown algae, Sargassum mangarevense and Turbinaria ornate (Phaeophyta: Fucales), from Tahiti (French Polynesia). J. Applied Phycology, 20: 1033-1043.

(Received $31 / 8$ / 2016;

accepted $26 / 11$ / 2016) 


\section{التعبير الجينى الزائد للجلسرول ثري فوسفات ديهيروجينيز فى بعض طحالب المياه المالحة لمصر لالجرول}

هدي انور منصور، “منال إمام عاصم ، منال محمد امام ،عبد السلام شعبان و نعمات حسن مصطفي أنور منصوري قسم النبات و ثقسم الكيمياء الحيوية ـ كلية العلوم - جامعة عين شمس - القاهرة -

هنالك القليل من الدر اسات التى أهتمت بالمقارنة بين طحالب المياه العذبة و المياه

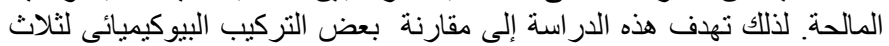

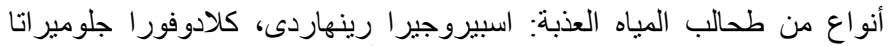

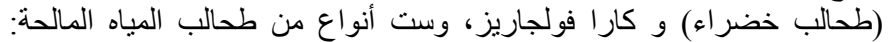

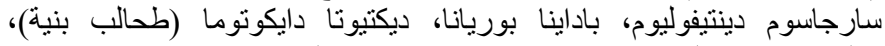

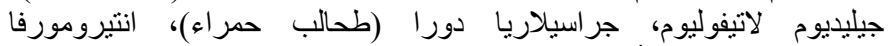

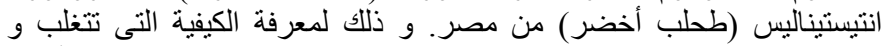

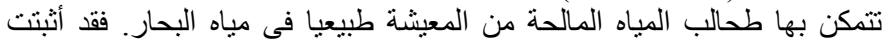

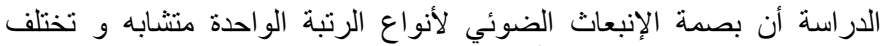

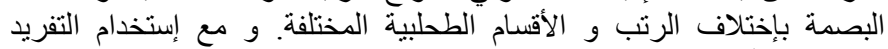

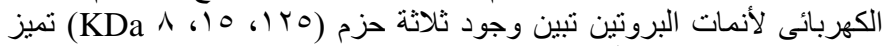

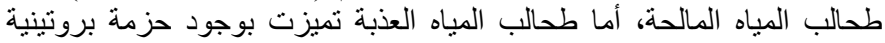

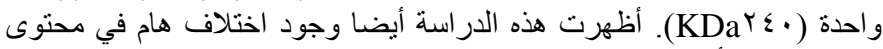

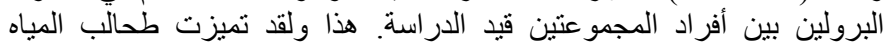

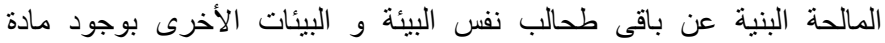

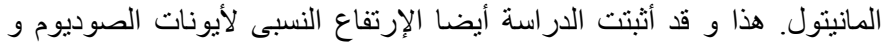

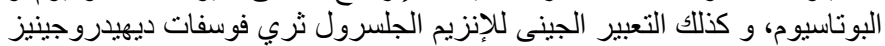

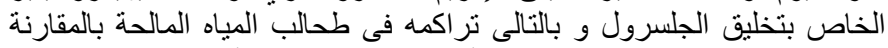

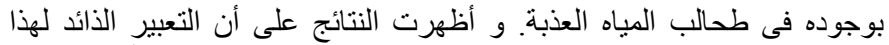
الإنزيم هو ما قد يمكن و يساعد الطحالب البحرية من المعيشة و التأقلم فى مياه 